\title{
MOBILE PHONE dan MEDIA SOSIAL: PENGGUNAAN dan TANTANGANNYA pada JURNALISME ONLINE INDONESIA
}

\author{
Ratna Puspita ${ }^{1}$, Titis Nurwulan Suciati ${ }^{2}$ \\ 1,2 IImu Komunikasi, Fakultas IImu Komunikasi, Universitas Bhayangkara Jakarta Raya
}

Naskah diterima tanggal 07-06-2020, direvisi tanggal 21-06-2020, disetujui tanggal 02-07-2020

\begin{abstract}
Abstrak. Artikel ini membahas mengenai tantangan jurnalis pada era mobile phone atau telepon seluler dan media sosial. Penulis berargumen, perubahan dan tantangan tidak hanya menyentuh organisasi media massa, kerja jurnalis, berita dan khalayak, namun hingga kepada ke tatanan nilai-nilai dan etika. Dengan melakukan kajian literatur dari penelitian-penelitian sebelumnya terkait perkembangan jurnalisme di Indonesia, penulis menyimpulkan media sosial tidak hanya berfungsi untuk medium promosi, melainkan medium menyampaikan berita pada era digital. Jurnalisme juga mengembangkan multimedia yang merujuk pada teknik presentasi atau penyajian berita yang memfokuskan pada tulisan dan gambar visual, baik bergerak maupun diam. Dengan melakukan kajian literatur dari penelitian-penelitian sebelumnya terkait perkembangan jurnalisme di Indonesia, penulis ingin memetakan seperti apa perubahanperubahan yang dialami jurnalisme online di Indonesia di tengah konsumsi seluler dan media sosial menyertakan tantangan-tantangan yang dialami jurnalisme online di Indonesia. Penggunaan perangkat mobile seperti telepon selular telah mendorong perubahan pada wajah jurnalisme di Indonesia. Sekarang ini, jurnalisme online di Indonesia berkembang pada konten multimedia dan multiplatform dengan media sosial sebagai penyebarannya. Praktik jurnalisme online sejak media 1990-an hingga sekarang telah mengalami perubahan yang berimbas tidak hanya pada konten berita, melainkan juga pada organisasi media, jurnalis, kode etik, termasuk adanya praktik di mana organisasi non-media memproduksi tulisan dalam kemasan 'jurnalisme' untuk tujuan branding dan pemasaran.
\end{abstract}

Kata kunci: Jurnalisme Online, Media Sosial, Mobile Communication

Abstract. This article discusses the challenges of journalists in the era of mobile phones or social media. The authors argue, changes and challenges for the mass media not only involved in organizations, the work of journalists, news, audiences, but also journalism values and ethics. By conducting a literature review from previous studies related to the journalism in Indonesia, the authors concluded that social media does not only function as a promotional medium but also a new medium for news presentation in the digital era. Journalism also develops multimedia which refers to presentation techniques of news that focuses on writing and visual images, both moving and still photo. By reviewing the literature from previous studies related to the development of journalism in Indonesia, the authors mapped the changes in online journalism in Indonesia amid cellular and social media consumption. The discussion includes the challenges for online journalism in Indonesia. The use of mobile devices such as cellular phones has driven changes in the face of journalism in Indonesia. Today, online journalism in Indonesia is developing multimedia and multiplatform content with social media as its medium. The practice of online journalism since the mid-1990s until now has given impact not only on news content but also on media organizations, journalists, codes of ethics. In this era also emerge sites that present messages similar to journalism but for the purpose of branding and marketing.

Keywords: Online Journalism, Social Media, Mobile Communication 


\section{PENDAHULUAN}

Praktik jurnalisme tidak pernah dapat dipisahkan dari perkembangan teknologi. Dari mulai percetakan hingga ke internet, teknologi membentuk dan memengaruhi jurnalisme. Mesin cetak, yang memunculkan koran, memungkinkan distribusi berita secara massal dalam bentuk kertas berisi tulisan dan gambar. Telegraf mempercepat proses, memungkinkan jurnalis untuk mengirimkan berita sehingga orang bisa mengetahui berita pada hari kejadian. Radio dan televisi membawa lebih banyak kedekatan dengan jurnalisme, cara baru dalam bercerita. Cerita yang ditampilkan menjadi lebih hidup karena mampu menampilkan gambar bergerak atau video. Lalu internet datang dan kemudian membawa warna lain berupa jurnalisme online. Kehadiran internet memungkinkan para jurnalis sekarang membawa audiens ke panggung berita melalui penggunaan audio, video, dan laporan langsung.

Namun, perkembangan teknologi komunikasi digital menghadirkan tantangan sekaligus peluang bagi perkembangan jurnalisme online. Aplikasi media sosial yang diakses melalui telepon selular (mobile phone) menjadi medium baru penyampaian berita. Haewoon Kwak, Changhyun Lee, Hosung Park, dan Sue Moon melakukan studi tentang media sosial Twitter yang memiliki kekuatan sebagai media penyebaran informasi pada 2010. Kwak, Lee, Park, \& Moon (2010) menjelaskan Twitter bukan hanya media untuk membangun hubungan sosial, melainkan juga mengetahui topik yang sedang trending atau banyak dibicarakan (trending topics). Berdasarkan analisa yang dilakukan oleh Kwak, Lee, Park, \& Moon (2010) (2010) bahwa trending topics tersebut berdasarkan judul berita atau berita. Kondisi ini kemudian memunculkan pendapat bahwa Twitter dapat menjadi media penyiaran berita.

Oscar Westlund secara konsisten melakukan penelitian tentang teknologi telepon seluler dan jurnalisme. Westlund (2008) melakukan penelitian adopsi teknologi telepon seluler dalam praktik jurnalisme, khususnya produksi konten multimedia. la menyatakan, "Teknologi telepon seluler (mobile phone) telah berubah dari komunikasi berbasis suara dan teks menjadi perangkat multimedia." Westlund (2008) menyimpulkan berdasarkan survei selama tiga tahun, yakni 2005 sampai 2007, gawai mobile memang belum menunjukkan dampak signifikan sebagai perangkat multimedia. Namun, ketika itu ada peningkatan merujuk pada tren penggunaan. Kala itu, pengadopsi awal (early adopters) yang umumnya berjenis kelamin laki-laki dan berusia 15 sampai 49 tahun telah menggunakan mobile gadget sebagai medium berita. Mobile gadget menjadi media berita tambahan dari media berita lainnya.

Westlund (2013) kembali melakukan riset terkait teknologi telepon seluler, multimedia, dan jurnalisme. Kali ini, Westlund menggunakan istilah "mobile news" atau berita seluler untuk menjelaskan teknologi layar sentuh pada perangkat mobile telah mengubah produksi dan konsumsi layanan berita. "Mengakses berita melalui mobile telah menjadi daya tarik dalam kehidupan sehari-hari masyarakat. Institusi berita juga telah mengembangkan konten jurnalistik dengan mengembangkan aplikasi dan situs untuk mobile".

Istilah mobile news merujuk pada praktik media massa melakukan "pendekatan berbeda dalam menggunakan perangkat mobile untuk reportase dari lapangan, dan pendekatan khusus untuk jenis konten apa yang akan diterbitkan untuk perangkat seluler". Mobile news ini meliputi bentuk jurnalisme untuk platform berita mobile, jurnalis mobile, dan jurnalisme warga pada era media mobile (Westlund, 2013). Umair (2016) menjelaskan "jurnalisme mobile merujuk pada cara tercepat untuk menyebarkan berita menggunakan media sosial dan situs berbagi video dan foto". Jurnalisme seluler merupakan hasil revolusi dari telepon seluler. Telepon seluler telah mengubah wajah jurnalisme mulai dari kemunculan jurnalis warga sebagai tokoh baru dalam penyebaran informasi hingga reporter yang memberikan laporan melalui teknologi mobile gadget. 
Irawan (2014) dalam penelitiannya "Aplikasi Citizen Journalism di Era Konvergensi Media" menjelaskan jurnalisme online adalah perkawinan antara jurnalisme konvensional dan teknologi komunikasi-dalam hal ini internet, yang ditetapkan oleh standar world wide web (www). Berdasarkan penjelasan Irawan, jurnalisme online merupakan proses pelaporan dan penyampaian informasi atau fakta yang didistribusikan melalui internet-dan observasi terhadap praktik jurnalisme di Indonesia, penulis berpendapat ada tiga fase jurnalisme online di Indonesia. Fase tersebut, yakni fase memindahkan berita pada media cetak ke online, fase pelaporan yang mengejar kecepatan, dan fase multimedia dan multiplatform lewat data, visual interaktif, dan media sosial.

Fase memindahkan berita pada media cetak ke situs berita merupakan fase awal perkembangan jurnalisme online di Indonesia. Fase ini dimulai pada 1995. Republika.co.id menyajikan berita melalui internet pada Agustus 1995, disusul Kompas.com pada September 1995. Kala itu, jurnalisme online di Indonesia belum mengenal pelaporan dan penyampaian berita secara real time. Fase pelaporan yang mengejar kecepatan terjadi pada 1998 atau era reformasi ketika Detik.com mulai melakukan pelaporan dan penyajian berita real time dan up to date. Karakteristik real time dan up to date atau berita yang disajikan dengan segera dan dekat dengan waktu kejadian ini menjadi pembeda dari berita koran. Kehadiran dan kesuksesan Detik.com mendorong kehadiran media online lain yang melaporkan dan menyajikan berita seperti Okezone.com (2007), Inilah.com (2008), dan Viva.co yang sebelumnya bernama Vivanews.com (2008).

Praktik pada fase kedua ini seperti dijelaskan oleh Ward (Muliawanti, 2018) bahwa "Transformasi medium, industri, dan organisasi ini pun mengubah penyajian berita. Pada era media baru atau internet, jurnalisme online mengutamakan kesegaraan atau immediacy atau kecepatan menyampaikan informasi." Fase ketiga, yakni multimedia dan multiplatform. Pada fase ini, penyajian jurnalisme online bertransformasi tidak lagi sekadar mengandalkan dan mengejar kecepatan. Jurnalisme online seperti Tirto menyajikan tidak mengandalkan pelaporan dan penyajian berita dengan cepat, melainkan melalui data infografis dan visual interaktif. Pada fase ini, media sosial tidak lagi sekadar mempromosikan atau medium membagikan link berita, tetapi juga medium untuk melaporkan dan menyajikan berita melalui format videografis yang merupakan perpaduan antara foto, dan grafis yang dikemas bergerak (video). Pada fase ketiga juga muncul bentuk jurnalisme baru yang mengembangkan kolom opini pada surat kabar.

Munculnya jurnalisme baru yang ada pada fase ketiga di atas sangat erat kaitannya dengan konsumsi berita oleh khalayak. Dalam bukunya "Mobile and Social Journalism", Adornato (2017) menyatakan bahwa konsumsi audiens merupakan bagian penting dari lanskap berita yang berkembang. Konsumsi berita sedang mengalami perubahan mendasar, yakni melalui perangkat mobile dan media sosial. "Berita adalah ponsel" karena ponsel telah menjadi perangkat dominan untuk konsumsi berita, sedangkan "berita bersifat sosial" karena pengguna internet lebih memilih mencari berita melalui media sosial ketimbang mengetik langsung alamat situs berita. Tautan yang dibagikan melalui media sosial seperti Facebook dan Twitter-atau disebut dengan "rujukan sosial" merupakan sumber penting. Selain itu, pengguna internet juga lebih sering 'mendengar' berita dari pengguna lain di media sosial (Adornato, 2017).

Molyneux (2018) mengatakan sesi mengakses berita melalui perangkat gawai sebenarnya lebih pendek dibandingkan pada platform lain. Kendati demikian, konsumsi berita seluler melalui perangkat berita terjadi "lebih banyak per hari dan tersebar sepanjang hari" (Molyneux, 2018). Penulis berargumen perkembangan jurnalisme kontemporer semacam di atas tidak hanya menghadirkan tantangan pada tiga hal yang disebutkan oleh Westlund, yakni berita baik dari sisi kemasan maupun isi, jurnalis, dan pembaca yang ditandai dengan keterlibatan sebagai jurnalis warga. Teknologi mobile phone juga menghadirkan tantangan bagi organisasi 
media massa, dan nilai-nilai dan etika jurnalisme tradisional. Dengan demikian, artikel ini akan memfokuskan pada pemasalahan dan tantangan jurnalisme di era mobile communication, khususnya di konteks jurnalisme tanah air. Dengan memetakan tantangan jurnalisme tersebut, diharapkan dapat menjadi pemantik penelitian-penelitian yang berfokus pada permasalahan jurnalisme tanah air, berikutnya. Penelitian dilakukan dengan pendekatan kajian literatur dari penelitian-penelitian sebelumnya terkait perkembangan jurnalisme di Indonesia. Dimulai dengan memetakan seperti apa perubahan-perubahan yang dialami jurnalisme online di Indonesia di tengah konsumsi seluler dan media sosial menyertakan tantangan-tantangan yang dialami jurnalisme online di Indonesia. Pada penelitian ini, penulis mengelompokkan penelitian-penelitian terdahulu menjadi beberapa kelompok, yakni situs berita, situs opini, situs agregator, media alternatif dan media pemerintah, media sosial, dan televisi streaming. Dengan memetakan tantangan jurnalisme tersebut, diharapkan dapat menjadi pemantik penelitian-penelitian yang berfokus pada permasalahan jurnalisme tanah air.

\section{METODE PENELITIAN}

Penulis melakukan kajian literatur dengan systematic review dari penelitian-penelitian sebelumnya terkait perkembangan jurnalisme di Indonesia. Dempster (Hanley \& Cutts, 2013) menjelaskan systematic review sebagai tinjauan menyeluruh terhadap literatur berbeda mengenai sebuah topik yang berbeda dengan tinjauan literatur tradisional. Dalam penelitian ini, penulis mengumpulkan studi-studi terdahulu mengenai jurnalisme online di Indonesia untuk kemudian menggambarkan tentang kemungkinan tantangan yang muncul terkait praktik jurnalisme.

\section{HASIL PENELITIAN DAN PEMBAHASAN}

Dalam penelitian yang menggunakan metode tinjauan literatur sistematik ini, data yang digunakan dapat dibagi menjadi dua. Pertama, artikel atau karya ilmiah yang memuat jurnalisme online sebagai pembahasan utamanya; kedua, artikel-artikel lepas non-saintifik yang membahas jurnalisme online dan berita online. Data pertama penulis kumpulkan dari hasil pencarian melalui situs repositori (penyimpanan) jurnal, yakni garuda.ristekdikti.ac.id dan neliti.com, dengan alasan bahwa website tersebut memungkinkan hasil pencarian artikel dari beragam jurnal, tidak dibatasi oleh penerbitannya. Pada situs mesin pencari Google Scholar, penulis memasukkan kata kunci "jurnalisme online", "berita online", dan "media online" dengan rentang dari tahun 2009 hingga 2019. Kata-kata kunci tersebut dipilih berdasarkan pada kata kunci yang ditarik dari pertanyaan-pertanyaan penelitian. Hasil yang didapat adalah total 105 artikel. Jumlah tersebut dapat disebut sebagai populasi dari penelitian ini.

Langkah selanjutnya, penulis membangun kerangka sampel dari total populasi tersebut. Penulis menentukan sampel penelitian berdasarkan tujuan penelitian, yakni jurnalisme online melalui situs berita, situs pengumpan atau agregator, situs opini, dan media sosial. Selain itu, penulis memilih sampel berdasarkan elemen yang terlibat dalam produksi berita, yakni organisasi media, jurnalis, dan berita. Penulis melakukan analisis terhadap 55 jurnal penelitian mengenai jurnalisme online di Indonesia untuk memetakan kondisi dan tantangan jurnalisme online di Indonesia sekarang ini. Jurnal-jurnal tersebut merupakan jurnal yang tersedia secara terbuka di internet, khususnya yang tersedia melalui repositori ilmiah seperti garuda.ristekdikti.go.id dan neliti.com. 
Dari 55 jurnal tersebut, penulis mencermati bahwa subyek penelitian pada penelitian di Indonesia terkait jurnalisme online tidak hanya terkait situs berita atau portal berita. Situs berita memang menjadi subyek penelitian paling banyak, yakni 43 penelitian. Namun, medium atau platform lain di internet juga menjadi subyek penelitian, yakni media sosial (empat penelitian), situs agregator (tiga penelitian) baik yang mendapatkan konten berita dengan cara bekerja sama dengan situs berita seperti Line Today maupun yang mendapatkan konten berita dengan cara ilegal, situs opini seperti Magdalene dan situs-situs Islam, dan media alternatif Good News From Indonesia (GNFI) serta media pemerintah seperti Infopublik yang dikelola oleh Kementerian Komunikasi dan Informatika (Kemenkominfo).

Variasi subyek penelitian ini menunjukkan perkembangan jurnalisme online atau jurnalisme pada era digital. Praktik jurnalisme online atau jurnalisme pada media baru yang mengandalkan media baru bukan hanya situs berita, melainkan juga melibatkan platform lain seperti situs opini yang merupakan, situs indeks atau situs agregator, media sosial, dan televisi streaming. Media sosial bagi organisasi media massa juga awalnya berfungsi untuk medium promosi berita. Namun, perlahan media sosial menjadi medium menyampaikan berita pada era digital. Seperti halnya pada situs berita, media sosial yang digunakan untuk menyampaikan berita sesuai dengan karakteristiknya juga harus mengedepankan kredibilitas.

Sebagai media promosi, media sosial berfungsi sebagai medium untuk menarik lebih banyak pembaca. Media sosial bisa meningkatkan keterikatan (engagement) pembaca berita sehingga mereka bisa merespons berita dengan beragam cara mulai dari memberikan komentar, membagikan ke media sosialnya, hingga membaca isinya. Namun, pelibatan media sosial dalam praktik jurnalisme online di Indonesia tidak sekadar sebagai medium untuk membagikan link yang akan mengarahkan pembaca pada berita. Media sosial juga punya dua fungsi lain, yakni sebagai sumber berita sehingga mengembangkan praktik-praktik jurnalisme warga dan medium melaporkan dan menyajikan berita.

Praktik menjadikan media sosial sebagai sumber berita ini seperti dijelaskan oleh Muliawanti (2018) bahwa jurnalisme online melibatkan penggalian informasi dan observasi virtual. Penggalian informasi dan observasi virtual ini dilakukan melalui media sosial. Lase (2015) menjelaskan praktik menjadikan media sosial sebagai sumber berita menunjukkan "pembauran atau perkawinan antara media online dengan media sosial". Praktik ini disebut juga dengan istilah hybrid journalism atau jurnalisme hibrida, yaitu "jurnalisme online arus utama menjadikan media sosial sebagai sumber informasi berita" (Lase, 2015). Jurnalisme online mengambil kontenkonten berita dari jejaring sosial seperti Facebook dan Twitter, kemudian menyadurnya menjadi sebuah berita.

Lase (2015) dalam penelitian memperlihatkan praktik jurnalisme hibrida ini dilakukan oleh Kompas.com melalui Kompasiana, yang merupakan ruang bagi jurnalisme warga. Awalnya, Kompasiana merupakan laporan dari warga yang ditulis dalam blog. Namun, jurnalisme hibrida ini bergeser menjadi praktik McDonaldisasi, yaitu tindakan yang dianggap rasional tetapi sebetulnya irasional, dengan menekankan pada prinsip-prinsip restoran cepat saji yakni efisiensi, kalkulasi, prediktabilitas dan kontrol. Dalam praktiknya, Kompas.com mengintegrasikan konten Kompasiana dalam sajian beritanya. Kompas.com mengunggah ulang tulisan pada Kompasiana sebagai berita resmi dari Kompas.com. Judul, lead, isi dan penutupnya tak jauh berbeda dari blog aslinya. Pemilik blog dijadikan sebagai narasumber meskipun proses perolehan data (data gathering) hanya sebatas dari unggahan di Kompasiana (Lase, 2015).

Sementara praktik menjadikan media sosial sebagai medium pelaporan berita ini sesuai dengan studi yang dilakukan oleh Pangaribuan (2017) bahwa media sosial juga dapat menjadi sarana mengunggah dan menyebarluaskan berita. "Media sosial bukan sekadar medium untuk 
mempromosikan berita, melainkan medium penyapai berita sehingga juga harus memenuhi unsur kredibilitas seperti trustworthiness, believeability, dan accuracy" (Pangaribuan, 2017).

Pangaribuan (2017) menjelaskan teknik penyajian berita pada media sosial, yakni berita disampaikan dengan singkat dalam format yang memfokuskan pada visual seperti video atau videografis dengan durasi maksimal satu menit. Format berita singkat ini membuat berita atau fakta yang dapat dimuat hanya berupa highlight atau difokuskan pada informasi yang dianggap penting dan menarik" Untuk itu, berita pada media sosial tidak dapat memenuhi unsur melaporkan seluruh cerita atau melaporkan cerita dengan utuh (report the whole story). Informasi tambahan dapat diberikan melalui caption atau keterangan gambar. Namun, informasi tambahan ini juga tidak bisa dibuat terlalu panjang untuk menarik minat pembaca.

Berita yang diunggah juga harus memenuhi unsur kebaruan, yakni current, timely, dan up to date, atau hangat, tepat waktu dan terkini. Berita yang diunggah segera setelah peliputan memiliki nilai kebaruan yang sangat tinggi. Kendati demikian, ada juga berita yang tidak diunggah segera setelah peliputan, yakni berita-berita yang memang tidak terkait dengan peristiwa. Namun, berita-berita tersebut tetap harus memiliki keterkaitan dengan kejadian terkini.

Perkembangan jurnalisme online hingga fase menjadikan media sosial sebagai medium berita ini menghadirkan tantangan. Muliawanti (2018) menjelaskan karakteristik jurnalisme online yang serba cepat dan harus up to date menggeser konsep-konsep tradisional jurnalisme online, baik terkait profesionalitas jurnalis maupun penyajian berita. Jurnalis tidak hanya mengunakan teknik pengumpulan informasi gaya lama seperti wawancara langsung dan observasi, melainkan juga melibatkan penggalian informasi dan observasi pada ruang virtual. Berita juga disajikan dengan ringkas, jurnalisme judul atau judul 'menarik', dan multiplatform.

Pergeseran juga terjadi pada khalayak media yang tidak lagi pasif, melainkan aktif sehingga melahirkan jurnalisme warga, dan media opini serta media alternatif yang membuka peluang bagi masyarakat untuk melaporkan dan mengirimkan video, gambar, tulisan, dan pendapat untuk ditayangkan kepada publik. Kemudian, kondisi ini juga mendatangkan tantangan bagi etika jurnalisme online.

Penulis juga menemukan hal lain yang menjadi tantangan bagi jurnalisme online sekarang ini, yakni situs agregator atau situs indeks atau pembaca umpan merupakan layanan pengumpulan berita yang bertujuan memudahkan pengguna internet mencari dan membaca berita, situs opini, situs disinformasi, dan situs-situs yang mengemas informasi dalam bentuk berita atau produk jurnalistik tetapi berfungsi sebagai branding (brand journalism). Untuk menjelaskan tantangan dari transformasi produksi berita di Indonesia, penulis akan menjelaskannya melalui sejumlah poin berikut: organisasi, jurnalis, berita online, situs agregator dan situs opini, situs disinformasi dan brand journalism.

\section{Organisasi Jurnalisme Online}

Internet menghadirkan tantangan bagi media massa sebagai organisasi yang menyajikan produk-produk jurnalisme. Media online sebagai organisasi yang melaporkan dan menyajikan berita melalui internet memiliki layanan informasi melalui tulisan, galeri foto, infografis, video atau televisi streaming, serta kolom komentar, forum diskusi, dan blog untuk menampung opini warga internet. Banyaknya bentuk penyajian informasi atau fakta ini menuntut media online melakukan perubahan struktur organisasi. Media online harus memiliki tim yang mampu memproduksi berita dalam bentuk tulisan, galeri foto, infografis, dan video streaming, serta mampu melakukan kurasi opini warga.

Praditya (2012) menjelaskan media online juga harus dapat diakses melalui gawai yang terkoneksi internet, termasuk perangkat mobile, dan telepon pintar. Untuk memudahkan 
pengguna mengakses berita lewat perangkat mobile, media online membuat aplikasi untuk telepon pintar seperti untuk Ipad, iPhone, dan perangkat berbasis Android. Penjelasan Praditya menunjukkan pentingnya infrastruktur teknologi informasi dalam pengembangan organisasi media online. Dengan demikian, media online juga harus memiliki bagian yang mengurus kebutuhan di bidang teknologi informasi meliputi keamanan server, penyimpanan berita di internet, perancangan aplikasi, tampil web baik dalam format desktop maupun telepon seluler, dan perancangan sistem mengunggah berita (sistem manajemen konten/CMS) yang memungkinkan redaktur mengunggah berita dalam bentuk multimedia (tulisan, foto, infografis, dan video).

Praditya (2012) juga menjelaskan mengenai integrasi media online dengan jaringan media sosial. "Media sosial digunakan untuk menampilkan berita-berita melalui link yang diunggah melalui situs jejaring sosial yang mengarahkan (directing) pembaca untuk membaca atau mengakses situs portal tersebut. Media sosial yang digunakan seperti Facebook, Twitter, dan Google+" (Praditya, 2012). Media online pun dituntut untuk memiliki staf yang bisa mengelola media sosial. Arifin (2018) menjelaskan redaksi media online memiliki staf yang mengelola media sosial sebagai sarana promosi. Pengelolaan media sosial ini meliputi pengumpulan database dan feedback, analisa data parametrik Facebook dan Twitter untuk mengetahui isu-isu terkini. Tidak hanya untuk mempromosikan berita melalui link, media sosial merupakan bagian media baru sehingga dikembangkan menjadi medium untuk menyampaikan berita atau reportase melalui media sosial.

\section{Tantangan Bagi Jurnalis}

Meski organisasi berita mengalami perubahan pada era online, tidak demikian dengan jurnalis atau orang yang bertugas melaporkan berita. Jurnalis atau wartawan merupakan profesi untuk orang-orang yang melaporkan fakta, baik fakta peristiwa atau kejadian maupun fakta pendapat atau pernyataan narasumber, setelah melakukan pengumpulan fakta melalui wawancara, reportase, atau penggalian dokumen. Akifah (2012) mengatakan jurnalis bekerja berdasarkan prinsip jurnalisme. Untuk itu, blogger atau siapa pun yang melakukan praktik jurnalisme warga terpisah dari jurnalis meski mampu memberikan informasi yang akurat dan obyektif tanpa sepenuhnya dipengaruhi oleh pemikiran mereka.

Kendati definisi jurnalis atau wartawan tidak mengalami perluasan pada era digital, tugas jurnalis pada era digital ini menjadi lebih banyak. Karakter media online yang multiplatform dan multimedia ini menuntut jurnalis untuk memiliki banyak kemampuan (multiskills) dan mampu mengerjakan banyak pekerjaan secara bersamaan atau multitasking. Rusadi (2013) menjelaskan "jurnalis sebagai human actor menyesuaikan kompetensinya dengan sistem manajemen multiplatform, yaitu menjalankan struktur dengan mengembangkan kompetensi dasar meliputi kesadaran diskursif, praktis dan motivasi kognitif dan mengembangkan kompetensi lunak media online yaitu sikap kerja cepat, multitasking dan memiliki orientasi kerja berjejaring sosial".

Muliawanti (2018) mengatakan "jurnalis online harus dapat menunjukan kreativitas para jurnalis untuk mengoptimalkan jurnalisme yang sesungguhnya, yaitu dituntut untuk lebih terampil dalam penyediaan konten baik visual, maupun penulisan. Jurnalis online juga dituntut untuk lebih cepat dan kreatif dalam berinovasi di bidang penampilan berita dan informasi”. Adzkia (2015) menjelaskan "jurnalisme online yang ditopang oleh internet menuntut wartawan untuk bisa menulis, memotret, membuat berita video, bahkan berinteraksi dengan audiens".

Penulis menyimpulkan bahwa sistem multiplatform media online mengharuskan jurnalis memiliki banyak kemampuan (multiskills) atau mempunyai banyak kreativitas dalam reportase atau pelaporan berita. Kreativitas tersebut meliputi pelaporan dalam bentuk tulisan dan visual seperti video dan foto. Pelaporan dalam beragam bentuk pesan tersebut juga harus dilakukan 
dengan cepat, yang tidak mengabaikan kemampuan menelaah dan menganalisis fakta dan menjaga akurasi.

Selain itu, jurnalis online juga harus memiliki kemampuan menganalisis media sosial mulai dari isu yang ramai dibicarakan oleh warga internet (warganet) hingga menarik minat mereka untuk berinteraksi (engagement) dengan berita dan media mereka. Jurnalis online juga disarankan harus paham karakter audiens yang akan mengonsumsi produk jurnalistiknya. Penyajian melalui berbagai platform memudahkan persebaran dan memperluas keterbacaan (Adzkia, 2015).Tuntutan untuk memiliki banyak kemampuan dan melaporkan berita dengan cepat ini mendorong wartawan untuk melakukan banyak pekerjaan dalam waktu bersamaan (multitasking). Dalam istilah yang lebih luas, bagaimana perangkat seluler dan media sosial memengaruhi rutinitas jurnalis sehari-hari. Ada tiga bidang yang perlu dipertimbangkan: berita, distribusi berita, dan keterlibatan audiens.

Sebelum jurnalis pergi ke rapat redaksi, jurnalis memantau berbagai media sosial seperti Facebook dan Twitter untuk mengetahui isu/peristiwa apa yang terjadi. Rutinitas sehari-hari sebagai seorang jurnalis sangat berbeda dari tahun-tahun sebelumnya, ketika jurnalis memperoleh isu dengan menelepon ke kantor polisi, memeriksa melalui telepon dengan sumber resmi lainnya, dan menyaring rilis berita. Jurnalis sekarang memiliki akses langsung ke banyak materi selama proses pengumpulan berita. Distribusi berita pada era mobile dan media sosial mengharuskan jurnalis untuk berbagi di berbagai platform saat mereka melaporkan dari lapangan. Jurnalis terutama jurnalis online lazim menggunakan perangkat seluler untuk meliput, memproduksi, dan mempublikasikan konten. Karena audiens mengharapkan informasi secara real time dari berbagai platform, jurnalis harus segera berbagi informasi ketika mereka melaporkan dari lapangan. Ini artinya jurnalis harus menyulap informasi menjadi santapan yang lengkap dan memuaskan kepada audiens yang aktif di banyak ruang Twitter, Facebook, situs web, dan aplikasi seluler.

Teknologi mendekatkan orang pada tidak hanya dengan berita yang diliput, tetapi juga baginya sebagai seorang jurnalis. Melalui media baru dengan karakter interactivity-nya, audiens dan jurnalis mampu terhubung hampir setiap saat. Hal ini membawa peluang dan tantangan baru bagi jurnalis. Adornato (2017) menawarkan ide berupa "kolaboratif" sebagai sebuah gagasan membawa audiens ke dalam proses pelaporan, lain juga adanya sikap keterbukaan dan responsif terhadap umpan balik audiens. Menurut Adornato (2017), "berita adalah sebuah percakapan, bukan ceramah. Jurnalis harus membiasakan mendengarkan, tidak hanya memuntahkan informasi atau mempromosikan cerita Anda. Semua pendekatan ini akan membuat penonton merasa diinvestasikan dalam pekerjaan Anda sebagai jurnalis".

Penulis berpendapat sebaliknya. Pada era media sosial dan mobile communication, orang bisa saja "mempublikasikan" konten, tetapi itu tidak menjadikan mereka jurnalis. Jurnalis memiliki keterampilan untuk memasukkan informasi ke dalam konteks, memverifikasi, dan memeriksa fakta. Keterampilan jurnalis dibutuhkan sekarang lebih dari sebelumnya untuk membantu audiens menavigasi melalui "kebisingan" untuk memahami banyaknya informasi (salah). Media sosial adalah jalan untuk membiarkan orang masuk tentang apa yang proses jurnalistik lakukan. Harapannya adalah melalui keterlibatan audiens dalam pelaporan, audiensi aktif mengenali nilai jurnalis, dan yang membuat audiens kembali untuk mendapatkan lebih banyak pada platform yang mereka pilih.

\section{Tantangan Jurnalisme Online Dari Aspek Pesan (Berita)}

Panuju (2018) yang melakukan penelitian berita bencana yang ditayangkan oleh Balipost.com menjelaskan bahwa berita bertumpu pada informasi dari sumber berita sahih 
sehingga terhindar dari pencampuran fakta dan opini. Narasumber berita sahih ini merupakan orang yang terlibat dengan peristiwa seperti pemerintah, dan masyarakat seperti pelaku bisnis. Temuan lainnya, karakteristik berita pada media online serupa dengan berita pada media lama, yakni memfokuskan pada fakta, baik fakta peristiwa yang bersumber pada kejadian maupun fakta pendapat yang berisi pendapat narasumber. Unsur berita online juga masih terdiri dari $5 \mathrm{~W}+1 \mathrm{H}$ (Who, What, When, Where, Why, dan How).

Rossy dan Wahid (2015) yang melakukan penelitian berita pemerkosaan pada Detik.com menunjukkan bahwa kelengkapan unsur $5 \mathrm{~W}+1 \mathrm{H}$ membantu menjelaskan dengan detail pada penulisan berita yang menonjolkan informasi. Namun ada perbedaan atau kekhasan yang muncul pada berita pada jurnalisme online. Pada era media lama, berita harus sudah selesai diverifikasi, bahkan melibatkan banyak narasumber, ketika hendak dimuat dan disebarkan kepada khalayak. Namun, proses tersebut tidak berlangsung pada jurnalisme online yang menerapkan verifikasi setelah berita dimuat atau pascaverifikasi.

Muliawanti (2018) menjelaskan bahwa "pergeseran penyajian berita, di antaranya praktik disiplin verifikasi yang dilakukan sebelum berita dimuat (praverifikasi) menjadi verifikasi setelah berita dimuat (pascaverifikasi)". Jurnalisme online akan menayangkan informasi atau fakta secara sepenggal-sepenggal sesuai dengan perekmbangan informasi yang telah didapatkan dan dikumpulkan oleh wartawan. Kondisi ini pula yang membuka kemungkinan unsur $5 \mathrm{~W}+1 \mathrm{H}$ tidak disajikan lengkap dalam satu berita, melainkan pada beberapa berita.

Karakteristik lain yang berbeda tersebut terlihat dari bahasa Indonesia jurnalistik, dan kemasan yang multimedia. Jurnalisme multimedia menekankan pada teknik presentasi atau penyajian berita yang menggabungkan visual tulisan dan gambar, baik bergerak maupun diam. Selain itu, jurnalisme multimedia ditunjukan dengan karakteristik media baru melalui penautan hypertextual, dan integrasi media sosial. Jurnalisme online sebagai jurnalisme multimedia ini menghadirkan berita dengan menggabungkan berbagai format, yakni tulisan, foto, audio, video, sehingga ada visualisasi data melalui infografis, dan videografis, serta adanya penautan hypertextual, dan integrasi media sosial.

Ciptadi \& Armando (2018) menjelaskan visualisasi data melalui infografis ini seperti dilakukan oleh Tirto. Tirto menyajikan jurnalisme yang mendalam dan penuh data dengan menyajikan ilustrasi data berbentuk infografik. Data infografik dibuat semenarik mungkin agar pembaca tertarik. Kendati demikian, Tirto juga tidak mengabaikan kredibilitas data. Tirto memiliki tiga level data yang digunakan untuk membuat infografis maupun mendukung penulisan artikel.

Sementara terkait bahasa Indonesia jurnalistik, penelitian yang dilakukan oleh Hardi (2015) menunjukkan bahwa struktur kalimat pada berita langsung pada jurnalisme online lebih banyak menggunakan kalimat sederhana, yakni singkat, padat, dan jelas. Akan tetapi, Hardi juga menjelaskan bahwa jurnalisme online masih menggunakan kalimat yang tidak efektif karena adanya ketidakjelasan dalam beberapa kalimat, ketidaktepatan pemilihan kata baku, ketidaktepatan pilihan kata, dan kerancuan atau ambiguitas makna (Hardi, 2015).

Dewi (2014) dalam studinya juga membeberkan bahwa jurnalisme online mengizinkan penggunaan bahasa tidak baku. Judul berita dengan bahasa baku pun tetap menarik perhatian pembaca. Bahasa nonbaku yang digunakan umumnya adalah bahasa asing, bahasa daerah, serta bahasa gaul yang digunakan anak muda. Judul yang digunakan untuk menarik perhatian pembaca ini kemudian memunculkan permasalah, yakni clickbait atau jurnalisme judul. Muliawanti (2018) menjelaskan penulisan ringkas dan judul yang menarik dalam kenyataannya justru melahirkan fenomena jurnalisme judul yang memberikan dampak ambiguitas antara judul dan konten berita. Muliawanti (2018) juga menjelaskan bahwa "teknik multimedia melalui penautan hypertextual memunculkan praktik chungking journalism atau jurnalisme tautan yang 
bergeser makna menjadi bukan untuk memberikan informasi pendukung melainkan untuk memenggal cerita dengan bersambung di laman lain yang ditautkan".

Tautan hypertextual bukan lagi untuk memudahkan pembaca untuk membagikan link ke media sosial atau memberitahu pembaca mengenai berita lain dengan topik terkait yang dapat menjadi informasi pendukung. Namun, tautan berubah menjadi cara media online untuk memenggal tulisan sehingga bersambung ke halaman berikutnya. Dengan demikian, pembaca harus mengklik banyak halaman untuk membaca utuh sebuah berita.

\section{Tantangan Jurnalisme dari Aspek Khalayak}

Khalayak juga mendatangkan tantangan bagi jurnalisme online. Lindawati (2015) dalam penelitiannya mengenai pola akses berita online pada kelompok usia anak muda menjelaskan bahwa anak muda sebagai digital natives menempatkan internet sebagai sumber berita utama. Digital natives merujuk pada generasi yang lahir setelah tahun 1980-an dan tumbuh dalam lingkungan digital. Lindawati (2015) menjelaskan bahwa anak muda terbiasa mengikuti perkembangan berita terkini. Anak muda memantau peristiwa terkini melalui linimasa media sosial. Dalam posisi ini, khalayak berita online menjadikan media sosial sebagai kurator. Dengan praktik ini, khalayak jurnalisme online bisa membandingkan berita dari beragam sumber. Di sisi lain, ketergantungan pada media sosial membuat khalayak jurnalisme online tidak konsisten dalam mengikuti perkembangan berita. "Hal ini berpotensi untuk menimbulkan pemahaman yang tidak utuh atas suatu peristiwa" (Lindawati, 2015).

Selain itu, kaum muda juga belum memberikan kepercayaan pada berita-berita jurnalisme online serta menilai berita pada surat kabar dan televisi masih menjadi media yang lebih dipercaya dibanding internet. Untuk itu, anak muda menilai kecepatan bukan karakter terpenting, melainkan kejelasan berita. Ini mendorong anak muda tidak hanya membutuhkan berita yang jelas dan ringkas, tetapi juga mendalam (Lindawati, 2015). Purnama \& Nugrahani (2013) yang melakukan penelitian mengenai preferensi anak muda dalam memilih situs berita online menjelaskan bahwa khalayak memilih situs berita berdasarkan pada kepercayaan, akses, desain situs web, akurasi, komunikasi, dan interaksi.

Sementara Arifin (2013) melakukan penelitian terkait kepuasan situs berita di Indonesia menyebutkan sejumlah dimensi terkait kepuasan khalayak pada situs berita online, yang diukur berdasarkan motivasi integrasi, interaksi sosial, pencarian informasi, identitas pribadi, dan pengalihan/hiburan. Hasil penelitian yang dilakukan oleh Arifin menunjukan bahwa tidak ada situs berita online yang berhasil memberikan kepuasan bagi khalayak pada semua dimensi. Detik.com yang paling memberikan kepuasan hanya mampu memenuhi kepuasan khalayak pada dimensi integrasi dan interaksi sosial, tetapi gagal memenuhi harapan khalayak untuk dimensi pencarian informasi, identitas pribadi, dan pengalihan/hiburan. Terkait integrasi dan interaksi sosial, khalayak merasa terbantu oleh Detik.com yang mampu membuat mereka menjadi percaya diri dalam aspek: tersalurkannya opini, memperoleh bahan pembicaraan dengan peer group, membantu menjalin relasi dengan orang lain (Arifin, 2013).

Kompas.com hanya mampu memenuhi kepuasan khalayak pada dimensi pencarian informasi. Sedangkan Viva.co.id, Okezone, Tempo.co, Mediaindonesia.com, dan Republika Online tidak mampu memenuhi satu pun harapan pemenuhan kepuasan dari khalayak. Temuan lain dalam penelitian ini, yakni responden mengakses berita online melalui link yang disertakan pada situs jejaring sosial semacam Twitter dan Facebook; responden mengakses berita melalui telepon seluler ( Arifin, 2013). 


\section{Tantangan Etika Jurnalisme Online}

Muliawanti (2018) mengelompokkan persoalan etika jurnalisme pada jurnalisme online pada tiga area, yakni pengumpulan berita, pelaporan berita, dan penyajian berita. Pada pengumpulan berita, wartawan dituntut untuk serba cepat sehingga membuka potensi melakukan plagiasi. Garini \& Besman (2018) menyebut plagiasi ini sebagai praktik jurnalisme. Kloning berita merujuk kepada perilaku wartawan yang melakukan kopi-salin atau copy paste atau menjiplak berita wartawan lain tanpa melakukan proses liputan sendiri”. Praktik ini juga terjadi karena wartawan tidak maksimal dalam proses mendapatkan bahan sehingga mengggunakan bahan milik wartawan lain, kemudian berita tersebut disiarkan atau dimuat di medianya dengan menggunakan nama wartawan yang melakukan kopi-salin.

Garini \& Besman (2018) mengatakan jurnalis online telah menganggap ini sebagai praktik yang wajar meski sangat dekat kaitannya dengan plagiarisme yang jelas-jelas tidak sesuai dengan Kode Etik Jurnalistik. Jurnalis online melakukan jurnalisme kloning bukan hanya desakan harus melaporkan dengan segera. Ada beberapa faktor yang mendorong jurnalis melakukan kloning di antaranya kerjasama dan solidaritas antarrekan wartawan, tuntutan pekerjaan wartawan media online untuk menghasilkan berita sebanyak-banyaknya dalam waktu sesingkatsingkatnya, kinerja individu wartawan, regulasi perusahaan media, dan perkembangan teknologi (Garini \& Besman, 2018).

Persoalan kedua, yakni terkait pelaporan berita di mana para jurnalis mengesampingkan verifikasi berita. Praktik mengesampingkan atau menunda verifikasi berita ini terjadi pada beritaberita yang bersumber pada media sosial seperti Twitter dan blog. Dalam praktik mengesampingkan verifikasi ini, Juditha (2016) menjelaskan situs berita memuat informasi hanya dari satu akun media sosial dan memperlakukannya sebagai kebenaran. Pada proses pelaporan ini, situs-situs berita tersebut tidak menguji kebenaran/ketepatan fakta kepada subyek, obyek, atau saksi berita. Ketika informasi tersebut ternyata salah (disinformasi), situs-situs berita itu pun harus memuat klarifikasi dan bantahan dari pihak yang terkait dengan berita.

Jurnalisme hibrida di Kompasiana yang menjadi bentuk Mcdonaldisasi juga mengabaikan verifikasi, yang seharusnya menjadi prinsip jurnalisme. Dalam praktik ini, Kompas.com memperlakukan Kompasiana sebagai medium yang memuat fakta sehingga tidak ada verifikasi. Dalam praktik ini, para jurnalis sekadar menyadur artikel-artikel dalam jurnalisme warga yang membuat jurnalis makin tercerabut dari kemampuan dan hakekat dirinya sebagai insan pers. Bentuk-bentuk inefesiensi, inkalkulasi, inprediktabilitas, serta lepas kendali yang justru menciptakan penurunan kualitas jurnalistik, homogenisasi konten, dan pemanfaatan tenaga jurnalisme warga (Lase, 2015).

Persoalan ketiga terkait penyajian berita, yakni pelanggaran etika mengenai independensi, ketidakjelasan narasumber berita, dan keberimbangan atau tidak cover both sides. Santoso dan Lestari (2018) menjelaskan pelanggaran etika ini trejadi karena adanya dorongan politik ekonomi. Dari sisi faktor ekonomi, jurnalisme online lebih mengutaman mengejar rating online (click dan page view). Sebab, setiap klik atau view berita berkaitan dengan orientasi profit, akumulasi modal, dan kalkulasi laba. Dari sisi faktor politik, pelanggaran etika jurnalistik dipengaruhi oleh afiliasi dan kepemilikan media terhadap calon pada kontestasi politik (Santoso \& Lestari, 2018).

Persoalan lain terkait etika jurnalistik pada jurnalisme online, yakni penggunaan jurnalisme robot. Amran \& Irwansyah (2018) menjelaskan "jurnalis robot dapat mengikuti prinsip penulisan berita sesuai kaidah elemen jurnalisme, tetapi belum seutuhnya mengenal etika jurnalisme layaknya manusia yang memiliki kesadaran akan etika". Jurnalis robot tidak bisa melakukan prinsip dasar elemen jurnalisme seperti verifikasi data ke lapangan, menjadi pemantau kekuasaan, menyediakan kolom komentar pada platform media, menulis berita 
dengan komprehensif serta menggunakan teknik berkisah yang menarik, dan jurnalis memiliki hati nurani ketika melakukan proses produksi berita yang memuat kepentingan masyarakat (Amran \& Irwansyah, 2018).

Adzkia (2015) jurnalisme memiliki tujuan melayani kepentingan bersama, yang tidak boleh diabaikan meski meski medium dan produksi berita mengalami transformasi. Jurnalisme online harus tetap mengutamakan kepentingan publik, dimulai dari menerapkan verifikasi dan menjaga akurasi, di tengah tuntutan menampilkan berita-berita secara cepat. Sebab, berita yang minus verifikasi dan akurasi bisa menyesatkan opini publik. Jurnalis pada era multimedia tidak boleh mengabaikan etika jurnalistik dan prinsip-prinsip dasar jurnalistik agar tetap bermanfaat bagi kepentingan publik.

\section{Situs-Situs Lain Pesaing Situs Berita}

Industri informasi di internet tidak hanya berisi berita. Internet memungkinkan siapa saja, baik individu maupun organisasi untuk menggunggah berita, cerita, dan berbagai tulisan lain. Dengan demikian, pada internet dapat ditemukan beragam bentuk informasi mulai dari pengumuman, promosi, iklan, dan konten-konten yang bertujuan membangun citra, hingga disinformasi. Bentuk perkembangan lain jurnalisme online yakni, situs opini. Keberadaan situs opini merupakan pengembangan dari kolom opini di media cetak. Situs berita juga memiliki kanal khusus yang menyajikan opini dari redaksi maupun dari luar redaksi. Namun, layanan informasi utama pada situs berita merupakan berita atau informasi yang mengandalkan pada fakta.

Situs opini seperti Magdalene menyajikan pendapat dari masyarakat yang ingin mengekspresikan pendapatnya mengenai perempuan. Sebuah tulisan yang tayang di Magdelene dapat mengundang tulisan lain, baik yang setuju maupun tidak setuju. Magdalene pun menjadi situs advokasi perempuan. Bagi pembaca, keberadaan media alternatif seperti Magdalene sangat baik bagi keberagaman. Situs lainnya, yakni situs agregator atau situs indeks seperti Line Today bekerja sama dengan sejumlah situs berita resmi untuk menyebarluaskan beritanya. Ini akan mendatangkan lalu lintas pada situs berita yang ditayangkan oleh agregator. Apalagi, agregator seperti Line Today tersemat pada media sosial percakapan Line. Kendati demikian, ada situs-situs agregator yang beroperasi ilegal atau tanpa dan kerja sama dengan situs berita resmi. Situs agregator ilegal ini mengambil berita dari situs berita kemudian mengunggah di lamannya. Keberadaan situs agregator ilegal ini mendatangkan masalah etika dan hukum.

Platform yang dapat menjadi tantangan bagi jurnalisme online, yakni situs-situs yang mengemas informasi dalam bentuk berita atau produk jurnalistik tetapi berfungsi sebagai branding (brand journalism) seperti Good News From Indonesia (GNFI) atau situs pemerintah. Pada era digital, perusahaan dan institusi pemerintah dapat membuat web yang memuat sejumlah kanal untuk memasarkan produk dan program mereka. Konsep serupa ini disebut sebagai brand journalism. Brand journalism adalah strategi multi-dimensional dan multi-dimensi untuk menciptakan cerita tentang merek. Ini berarti menceritakan banyak sisi kisah merek ketika semua orang sudah mengetahui merek tersebut dan makna merek tersebut (Light \& Kiddon, 2016).

Brand journalism merupakan strategi pemasaran yang pertama kali dilakukan oleh McDonald. Strategi ini menuntut orang-orang yang bekerja dalam komunikasi pemasaran, baik Public Relations atau Humas maupun periklanan, untuk berpikir dalam kerangka jurnalisme. Artinya, setiap artikel berbeda dari artikel lain dengan menyajikan subjek berbeda, topik berbeda, pesan berbeda; dan artikel disajikan dalam cara yang dinamis, menarik, relevan, dan koheren.

Light \& Kiddon (2016) memberi contoh brand journalism yang dilakukan oleh Cisco, sebuah perusahaan teknologi. Cisco membangun sebuah web dengan banyak kanal dan mencari 
penulis untuk membuat konten-konten yang mengoneksi dengan pelanggan. Elfrida (2015) melakukan penelitian tentang proses membangun agenda kebijakan pemerintah yang dilakukan Kementerian Komunikasi dan Informatika sebagai humas pemerintah melalui portal berita infopublik. Dalam penelitian ini, Elfrida (2015) menjelaskan Kementerian Komunikasi dan Informatika melakukan agenda setting dalam isu-isu strategis, khususnya tentang kebijakan dalam pelaksanaan pemilihan presiden. Dalam prosesnya, agenda setting pemerintah ini juga menjadi agenda jurnalisme online. Kesamaan agenda ini terlihat dari narasumber dan tematik berita (Elfrida, 2015).

Penulis memahami bahwa organisasi, baik perusahaan maupun institusi pemerintah, merupakan narasumber berita bagi jurnalis. Karena itu, situs pemerintah dan perusahaan yang dikelola oleh humas organisasi tersebut pun dapat menjadi sumber berita. Namun, tulisan-tulisan yang diunggah dalam situs-situs tersebut memiliki agenda untuk memasarkan produk, program, dan mengelola citra dari organisasi. Akan tetapi, pengutipan situs yang dikelola pemerintah tanpa diserta sikap kritis dan skeptis akan membuat jurnalisme online sekadar corong pemerintah. Dengan demikian, situs brand journalism menghadirkan kemudahan bagi wartawan mencari berita sekaligus menjebak jurnalis untuk mengikuti agenda setting atau pembingkaian yang dilakukan oleh organisasi yang seharusnya dikritisi oleh jurnalis.

Di sisi lain, kemudahan internet juga dapat memunculkan fenomena disinformasi di internet. Kondisi ini terlihat dari keberadaan situs-situs Islam yang menjadi corong propaganda sehingga adanya situs-situs yang mengandalkan opini, persepsi, dan pandangan ini menjadi tantangan bagi jurnalisme yang mengedepankan pada prinsip verifikasi. Ahmad (2013) menjelaskan banjir informasi (overload of information) pada era information society (masyarakat informasi) telah memunculkan beragam informasi, mulai dari informasi yang memberdayakan hingga informasi yang justru menyesatkan (disinformasi). Ahmad dalam penelitiannya terhadap situs-situs yang memuat disinformasi ajaran Islam menjelaskan ada sejumlah jenis situs di Indonesia.

Pertama, yakni situs berita seperti Detik.Com, Republika.Com, Tempointeraktif.Com, dan Kompas Cyber Media (KCM). Kedua, situs informasi tetapi yang memfokuskan hanya pada isuisu tertentu. Dalam konteks penelitian Ahmad, situs tersebut terkait dengan umat Islam dan keislaman seperti Eramuslim.com, Islamlib.com, swaramuslim.com, MyQuran.Com, Ukhuwah.or.id, Isnet.com, dan pesantrenvirtual.com. Ketiga, situs dari organisasi. Dalam konteks penelitian Ahmad, organisasi ini terkait dengan organisasi keagamaan dalam Islam seperti Muhammadiyah, Nahdhatul Ulama (NU), dan Persis. Keempat, situs yang memuat informasi yang tidak terverifikasi atau tidak memiliki dasar atau disinformasi (Ahmad, 2013).

Disinformasi merupakan tantangan bagi jurnalisme yang mengutamakan fakta. Dalam konteks kualitas pesan, disinformasi pun dapat dikatakan serangan bagi jurnalisme online. Sebab, disinformasi yang menggunakan judul bombastis dan sensasional lebih cepat menjadi perbincangan (viral) di internet dibandingkan informasi-informasi relevan dan penting bagi masyarakat. Keberadaan situs-situs disinformasi akan merugikan jurnalisme online dalam pasar bebas informasi di internet. Jurnalisme online harus melakukan cek fakta dan melakukan klarifikasi informasi yang menjadi perbincangan warga di internet. Kondisi ini yang kemudian mendorong jurnalisme online melakukan Cek Fakta.

Dhyatmika (2019) menjelaskan jurnalis pada era digital dapat melakukan cek fakta untuk melawan disinformasi dan misinformasi. Cek fakta merujuk pada format berita untuk melawan hoaks dan disinformasi. Dasar metodologi cek fakta dengan menerapkan prinsip jurnalisme, yakni disiplin verifikasi. Jurnalis memeriksa konten di internet yang memuat klaim tertentu. Prosedur ini penting agar artikel cek fakta tidak terjebak dalam klaim pernyataan yang sebenarnya tidak ada alias fiksi. 


\section{SIMPULAN}

Penggunaan perangkat mobile seperti telepon selular telah mendorong perubahan pada wajah jurnalisme di Indonesia. Sekarang ini, jurnalisme online di Indonesia berkembang pada konten multimedia dan multiplatform dengan media sosial sebagai penyebarannya. Praktik jurnalisme online sejak medio 1990-an hingga sekarang telah mengalami perubahan yang berimbas tidak hanya pada konten berita, melainkan juga pada organisasi media, jurnalis, kode etik, termasuk adanya praktik di mana organisasi non-media memproduksi tulisan dalam kemasan 'jurnalisme' untuk tujuan branding dan pemasaran.

Sementara itu, penelitian di Indonesia masih sangat sedikit yang mengkaji akan sosial sebagai media pelaporan dan penyajian berita. Demikian juga dengan penelitian mengenai model bisnis jurnalisme online yang menyajikan produk jurnalisme. Jurnalisme online di Indonesia berkembang pada tiga fase dan masih mungkin kembali mengalami perubahan. Perkembangan pesat internet dan segala hal yang berkaitan dengannya begitu sulit diprediksi menempatkan jurnalisme dalam situasi dan kondisi yang tidak pasti. Demikian juga dengan tantangan-tantangan yang harus dihadapinya.

\section{DAFTAR PUSTAKA}

Adornato, A. (2017). Mobile and Social Media Journalism: Practical Guide. California: CQ Press.

Adzkia, A. R. S. (2015). Praktik Multimedia dalam Jurnalisme Online di Indonesia. Jurnal Komunikasi, 10(1), 41-53. Retrieved from https://journal.uii.ac.id/jurnalkomunikasi/article/view/7489

Ahmad, A. (2013). Perkembangan Media Online dan Fenomena Disinformasi ( Analisis pada Sejumlah Situs Islam ) Online Media Development and Phenomenon of Disinformation ( Analysis of Islamic sites ). Jurnal Pekommas, 16(3), 177-186.

Akifah, O. A. (2012). Citizen Journalism : a Study of New Form of News Media Reporting. Jurnal Academica, 04(01), 774-782.

Amran, S. O., \& Irwansyah. (2018). Jurnalisme Robot dalam Media Daring Beritagar.id. IPTEKKOM, 20(2), 169-182.

Arifin, M. S. (2018). Manajemen Redaksional Portal Berita Online Dalam Mengelola Media Sosial Sebagai Sarana Promosi. Communication, 9(2), 1-6. Retrieved from https://journal.budiluhur.ac.id/index.php/comm/article/view/733

Arifin, P. (2013). Persaingan Tujuh Portal Berita Online Indonesia berdasarkan Analisis Uses and Gratifications. Jurnal ILMU KOMUNIKASI, 10(2), 195-211. https://doi.org/10.24002/jik.v10i2.353

Ciptadi, S. G., \& Armando, A. (2018). Upaya Agensi Melawan Logika Jangka Pendek Jurnalisme Daring: Studi Kasus Tirto.id. Jurnal Komunikasi Indonesia, 7(1), 62-72. https://doi.org/10.7454/jki.v7i1.9690

Dewi, M. (2014). Gaya Bahasa Berita Media Online di Indonesia: Judul Menarik Tidak Harus Tidak Baku. Humaniora, 5(2), 1015-1022. https://doi.org/10.21512/humaniora.v5i2.3212

Dhyatmika, W. (2019). Cekfakta: Tanggung Jawab Baru Jurnalisme Digital di Era Disinformasi. Retrieved November 22, 2019, from https://www.merdeka.com/peristiwa/cekfaktatanggung-jawab-baru-jurnalisme-digital-di-era-misinformasi.html

Elfrida, S. V. (2015). Proses Membangun Agenda Setting Kebijakan pada Portal Berita Pemerintah dan Kesesuaiannya dengan Agenda Media Online. Jurnal Masyarakat Telematika Dan Informasi, 6(1), 13-26.

Garini, T., \& Besman, A. (2018). (2739) 1-9. Mediator: Jurnal Komunikasi, 11(1), 1-9.

Hanley, T., \& Cutts, L. (2013). What is a systematic review. Counselling Pshychology Review, 
28(4), 4-6. https://doi.org/10.1136/ebn.2011.0049

Hardi, N. M. (2015). Tingkat Kepatutan Berbahasa Jurnalistik pada Jurnalisme Online di Situs detikbandung.com (Studi Deskriptif dengan Teknik Analisis Isi terhadap Penerapan Kaidah Bahasa Jurnalistik Berita Langsung (Straight News) di detikBandung.Com).

KOMUNIKATIF: Jurnal IImiah Komunikasi, 4(2-Desember), 33-44.

Irawan, R. E. (2014). Aplikasi Citizen Journalism di Era Konvergensi Media. Humaniora, 5(2), 816-821. https://doi.org/10.21512/humaniora.v5i2.3137

Juditha, C. (2016). News Objectivity and Journalism Ethics in Online Media: Case on BUMN Employees Recruitment (Obyektivitas Berita dan Etika Jurnalistik di Media Online: Kasus Rekrutmen Karyawan BUMN). Journal Pekommas, 1(1), 1-12. https://doi.org/10.30818/jpkm.2016.2010101

Kwak, H., Lee, C., Park, H., \& Moon, S. (2010). What is Twitter, a social network or a news media? Proceedings of the 19th International Conference on World Wide Web, WWW '10, 591-600. https://doi.org/10.1145/1772690.1772751

Lase, F. J. (2015). McDonaldisasi Melalui Praktik Jurnalisme Hibrida di Kompasiana. Jurnal ILMU KOMUNIKASI, 11(2), 135-150. https://doi.org/10.24002/jik.v11i2.414

Light, L., \& Kiddon, J. (2016). Six Rules of Brand Revitalization (2nd Edition): Learn the Most Common Branding Mistakes and How to Avoid Them. New Jersey: Perason Education, Inc.

Lindawati, L. (2015). Pola Akses Berita Online Kaum Muda. Jurnal Studi Pemuda, 4(1), 241259.

Molyneux, L. (2018). Mobile News Consumption: A habit of snacking. Digital Journalism, 6(5), 634-650. https://doi.org/10.1080/21670811.2017.1334567

Muliawanti, L. (2018). Jurnalisme Era Digital: Digitalisasi Jurnalisme Dan Profesionalitas Jurnalisme Online. LENTERA: Jurnal IImu Dakwah Dan Komunikasi, 2(1), 50-69. https://doi.org/10.21093/lentera.v2i1.1168

Pangaribuan, T. R. . (2017). Kredibilitas Media Sosial Dalam Pemberitaan Pemilihan Gubernur Dki Jakarta. Jurnal Penelitian Komunikasi Dan Pembangunan, 18(2), 75-90. https://doi.org/10.31346/jpkp.v18i2.1169

Panuju, R. (2018). Etika Jurnalistik dan Jurnalisme Bencana pada Pemberitaan Gunung Agung di Portal Berita Balipost.com. Jurnal ILMU KOMUNIKASI, 15(2), 219-232. https://doi.org/10.24002/jik.v15i2.1455

Praditya, D. (2012). Perkembangan Surat Kabar Digital di Era Konvergensi. Balai Pengkajian Dan Pengenmbangan Komunikasi Dan Informatika, 10(2), 135-146.

Purnama, S. D., \& Nugrahani, R. U. (2013). A Comparative Study of Online News Site Service Based on Consumer Preference to The Student of Telkom Institute of Management 2011 (Objective of Study: Detik.com, Kompas.com, Okezone.com, and Vivanews.com). Jurnal Sosioteknologi, 28(April), 263-276.

Rossy, A. E., \& Wahid, U. (2015). Analisi Isi Kekerasan Seksual Dalam Pemberitaan Media Online. Jurnal Komunikasi, 7(2, Desember), 152-164.

Rusadi, U. (2013). Kompetensi Jurnalis Sebagai Aktor Dalam Produksi Berita Media Multiplatform. Jurnal Studi Komunikasi Dan Media, 16(2), 111-122. https://doi.org/10.31445/jskm.2012.160202

Santoso, D. H., \& Lestari, R. D. (2018). Penerapan Etika Jurnalistik dalam Pemberitaan Politik di Media Online ( Studi Kasus Pemilihan Gubernur DKI Jakarta ) Application of Journalistic Ethics in Political Reporting in Online Media ( Case Study of the Governor Election of Jakarta ). Jurnal Pekommas, 3(2), 203-212.

Umair, S. (2016). Mobile Reporting and Journalism for Media Trends, News Transmission and its Authenticity. Journal of Mass Communication \& Journalism, 06(09), 1-6. https://doi.org/10.4172/2165-7912.1000323

Westlund, O. (2008). From Mobile Phone to Mobile Device: News Consumption on the Go. Canadian Journal of Communication, 33(3). https://doi.org/10.22230/cjc.2008v33n3a2004

Westlund, O. (2013). Mobile news: A review and model of journalism in an age of mobile media. Digital Journalism, 1(1), 6-26. https://doi.org/10.1080/21670811.2012.740273 